\title{
Inch Strip Dosing Unit
}

National Cancer Institute

\section{Source}

National Cancer Institute. Inch Strip Dosing Unit. NCI Thesaurus. Code C124231.

A dosing unit equal to the amount of active ing redient(s) contained in an inch ribbon of a topical substance. 